\title{
PENERAPAN BUDAYA ORGANISASI DALAM MENINGKATKAN KINERJA PADA DINAS KEPENDUDUKAN DAN PENCATATAN SIPIL KABUPATEN BANJARNEGARA PROVINSI JAWA TENGAH
}

\author{
Oleh \\ Muhammad Akbar Agung Pratama ${ }^{1}$, \\ Murtir Jeddawi², Sampara Lukman ${ }^{3}$ \\ 1) Program Magister Terapan Studi Pemerintahan Daerah Institut Pemerintahan Dalam Negeri \\ muhammad.akbaragung@yahoo.com \\ 2,3) Institut Pemerintahan Dalam Negeri
}

\begin{abstract}
$I^{\prime}$ the context of national development, the aspect of population is the basis for the achievement of development goals. However, in Banjarnegara District, there are tens of thousands residents who do not yet have an e-KTP. This is caused by the convoluted process of population administration services. In the concept of management, one effort to encourage performance is to pay attention to the culture inherent in the organization that is able to have a positive influence on employee performance. Therefore, the authors conducted research related to the implementation of organizational culture in the Department of Population and Civil Registration of Banjarnegara Regency.

In this study, the authors used a qualitative method with an inductive approach. The focus of this study is the application of work culture, service performance, inhibiting factors in improving performance and implementing organizational culture. This study selected participants in the interview using purposive sampling method. In addition, a document study was also conducted.

The results showed that the performance of the service had met the target targets of the service as outlined in the RPJMD. The first target is to improve the quality of excellent service to the community in the field of population and civil registration. The second target is to increase the orderly administration of the population of Banjarnegara. While in the context of the application of organizational culture the Office, in general, has carried out the organizational culture component in accordance with Robbins's theory. There are several factors why this can be applied, namely, first, is the size of the service organization that is not too large. Employee turnover in the scope of services is also not carried out too often so that the organizational culture is well embedded.
\end{abstract}

Keywords: organizational culture, performance, Population and Civil Registry Office

\begin{abstract}
Abstrak
$\mathrm{D}$ alam pembangunan nasional, aspek kependudukan merupakan dasar untuk tercapainya tujuan pembangunan. Akan tetapi, di Kabupaten Banjarnegara, ada puluhan ribu warga yang belum memiliki e-KTP. Hal ini disebabkan oleh berbelit-belitnya proses pelayanan administrasi kependudukan. Dalam konsep manajemen, salah satu upaya untuk mendorong kinerja adalah dengan memperhatikan budaya yang melekat pada organisasi tersebut yang
\end{abstract}


mampu memberikan pengaruh positif terhadap kinerja pegawai. Oleh karena itu, penulis melakukan penelitian terkait penerapan budaya organisasi pada Dinas Kependudukan dan Pencatatan Sipil Kabupaten Banjarnegara.

Pada penelitian ini, penulis menggunakan metode kualitatif dengan pendekatan induktif. Fokus kajian pada penelitian ini adalah penerapan budaya kerja, kinerja dinas, faktor penghambat dalam peningkatan kinerja dan penerapan budaya organisasi. Penelitian ini memilih partisipan dalam wawancara dengan menggunakan metode purposive sampling. Selain itu juga dilakukan kajian dokumen.

Hasil penelitian menunjukkan bahwa kinerja dinas telah memenuhi target sasaran dari dinas yang dituangkan dalam RPJMD. Sasaran pertama adalah meningkatnya kualitas pelayanan prima kepada masyarakat di bidang kependudukan dan pencatatan sipil. Sasaran kedua adalah meningkatnya tertib administrasi kependudukan masyarakat Banjarnegara. Sementara dalam konteks penerapan budaya organisasi Dinas secara umum telah melaksanakan komponen budaya organisasi sesuai dengan teori Robbins. Ada beberapa faktor penyebab hal tersebut bisa diterapkan, yakni pertama, adalah ukuran organisasi dinas yang tidak terlalu besar. Perputaran pegawai di lingkup dinas juga tidak terlalu sering dilaksanakan sehingga budaya organisasi tertanam dengan baik.

Kata kunci: budaya organisasi, kinerja, Dinas Kependudukan dan Pencatatan Sipil

\section{PENDAHULUAN}

$\mathrm{S}$ atu jenis pelayanan publik yang menjadi sorotan dan konsentrasi pemerintah baik pusat maupun daerah adalah pelayanan administrasi kependudukan. Dalam pembangunan nasional, aspek kependudukan merupakan dasar untuk tercapainya tujuan pembangunan, oleh karena itu wajib hukumnya pemerintah melaksanakan pelayanan kependudukan dan pencatatan sipil guna mendapatkan data kependudukan yang valid sebagai dasar pembuatan kebijakan kependudukan dan kebijakankebijakan sektoral lainnya. Melalui pelaksanaan otonomi daerah pemerintah memberikan wewenang kepada pemerintahan daerah untuk melaksanakan urusan pelayanan administrasi kependudukan dan catatan sipil.

Mengingat vitalnya peran administrasi kependudukan dan tingginya tuntutan pemenuhannnya Dinas Kependudukan dan Catatan Sipil pemerintah daerah Kabupaten Banjarnegara berupaya untuk dapat memenuhi ekspektasi rakyat dan melaksanakan kewajibannya sebagai provider pelayanan publik. Akan tetapi tingkat kinerja pelayanan administrasi kependudukan yang dilaksanakan Dinas Kependudukan dan Pencatatan Sipil Kabupaten Banjarnegara belum optimal. Dalam konsep manajemen, salah satu upaya untuk mendorong kinerja adalah dengan memperhatikan budaya yang melekat pada organisasi tersebut yang mampu memberikan pengaruh positif terhadap kinerja pegawai.

Budaya organisasi yang terbina dengan baik dalam organisasi akan berkontribusi terhadap perilaku pegawai yang selanjutnya akan bermuara pada prestasi kerja pegawai. Dalam organisasi, implementasi budaya dirupakan dalam bentuk perilaku, artinya perilaku individu dalam organisasi akan diwarnai oleh budaya organisasi yang bersangkutan. Perilaku pegawai yang sesuai dengan budaya organisasi tersebut akan memberikan efek pada meningkatnya kinerja pegawai, karena budaya perusahaan ditetapkan oleh manajemen demi mewujudkan visi dan misi perusahaan yang salah satunya adalah menciptakan kompetensi pegawai yang berkinerja tinggi. Dengan demikian budaya organisasi menjadi salah satu kriteria penting dalam 
menentukan pertumbuhan dan kesuksesan organisasi.

Sehubungan dengan fenomena yang terjadi sehingga muncul penilaian sekilas bahwa kualitas pelayanan administrasi kependudukan masih rendah maka penulis mengangkat judul dari penelitian ini, yaitu: "Penerapan Budaya Organisasi Dalam Meningkatkan Kinerja Pada Dinas Kependudukan dan Pencatatan Sipil Kabupaten Banjarnegara Provinsi Jawa Tengah".

\section{Identifikasi Masalah}

Berdasarkan fakta yang ada dalam pelaksanaan pelayanan administrasi kependudukan pada Dinas Kependudukan dan Pencatatan Sipil Kabupaten Banjarnegara maka peneliti mengidentifikasi masalah yang ada sebagai berikut.

a. Pelayanan belum optimal meski ada kebijakan yang sudah diambil untuk meningkatkan kinerja;

b. Pelimpahan kewenangan ke kecamatan belum menjadikan pelayanan yang optimal;

c. Pelayanan administrasi kependudukan terkesan dipersulit, terlihat dari waktu pelayanan yang tidak sesuai dengan standar pelayanan minimal sehingga banyak keluhan masyarakat mengenai pelayanan yang diberikan.

\section{Pembatasan Masalah}

Permasalahan dan Penelitian ini dibatasi dengan memperhatikan fokus dan lokus penelitian, adapun penelitian ini dibatasi pada permasalahan yang menitikberatkan pada penerapan budaya organisasi dalam upaya meningkatkan kinerja aparat Dinas Kependudukan dan Catatan Sipil Kabupaten Banjarnegara, khususnya yang berkaitan dengan Elektronik Kartu Tanda Penduduk (EKTP).

\section{Perumusan Masalah}

a. Bagaimana penerapan budaya organisasi dalam peningkatan kinerja pelayanan Administrasi Kependudukan pada Dinas Kependudukan dan Pencatatan Sipil Kabupaten Banjarnegara Provinsi Jawa Tengah?

b. Faktor apakah yang memengaruhi penerapan budaya organisasi Dinas Kependudukan dan Pencatatan Sipil dalam meningkatkan kinerja pelayanan administrasi kependudukan di Kabupaten Banjarnegara Provinsi Jawa Tengah?

c. Upaya apa saja yang dilakukan oleh Dinas untuk mengatasi hambatan budaya organisasi Dinas Kependudukan dan Pencatatan Sipil dalam meningkatkan kinerja pelayanan administrasi kependudukan di Kabupaten

Banjarnegara Provinsi Jawa Tengah?

\section{Maksud dan Tujuan Penelitian}

Adapun maksud penelitian ini adalah untuk menganalisis budaya organisasi dalam meningkatkan kinerja pelayanan administrasi kependudukan pada Dinas Kependudukan dan Pencatatan Sipil Kabupaten Banjarnegara Provinsi Jawa Tengah dalam rangka mewujudkan tertib administrasi kependudukan.

Sementara, tujuan dari penelitian ini adalah:

a. Untuk menganalisis dan memahami penerapan budaya organisasi dalam pelaksanaan pelayanan Administrasi

Kependudukan pada Dinas Kependudukan dan Pencatatan Sipil Kabupaten Banjarnegara Provinsi Jawa Tengah.

b. Untuk mengetahui faktor yang menjadi hambatan budaya organisasi Dinas Kependudukan dan Pencatatan Sipil 
dalam meningkatkan kinerja pelayanan administrasi kependudukan di Kabupaten Banjarnegara Provinsi Jawa Tengah.

c. Untuk mengetahui upaya sebagai solusi dari hambatan dalam Penerapan Budaya Organisasi Dalam Peningkatkan Kinerja

Pelayanan Administrasi Kependudukan Pada Dinas Kependudukan dan Pencatatan Sipil Kabupaten

Banjarnegara Provinsi Jawa Tengah.

\section{Kegunaan Penelitian}

\section{Kegunaan Praktis}

Penelitian ini diharapkan mampu memberikan sumbangan saran serta informasi khususnya bagi pemerintah Kabupaten Banjarnegara terutama Dinas Kependudukan dan Pencatatan Sipil dalam rangka penerapan budaya organisasi dan pencapaian kinerja pelayanan di bidang administrasi kependudukan.

\section{Kegunaan Teoretis}

Hasil penelitian ini diharapkan memberikan kontribusi bagi ilmu pemerintahan terutama konsep-konsep yang berkaitan dengan pelaksanaan manajemen administrasi sektor publik serta mengembangkan ilmu pengetahuan khususnya yang berkaitan dengan masalah kependudukan serta dapat dijadikan sebagai bahan informasi untuk pendalaman penelitian selanjutnya yang berkaitan dengan optimalisasi pendataan penduduk, khususnya bagi Dinas Kependudukan dan Catatan Sipil.

\section{KAJIAN PUSTAKA}

Penelitian terdahulu menunjukkan bahwa budaya organisasi memiliki pengaruh terhadap kinerja pada suatu organisasi. Yang membedakan adalah tingkat pengaruhnya ada yang biasa saja dan ada juga yang kuat. Penelitian yang akan dilaksanakan penulis memiliki fokus dan tujuan penelitian yang hampir sama. Yang membedakan adalah bahwa motode penelitian pada penelitian terdahulu banyak menggunakan metode kuantitatif. Sedangkan, pada penelitian ini akan digunakan metode penelitian kualitatif dengan pendekatan induktif. Perbedaan metode ini tentunya akan memberikan sudut pandang yang berbeda dengan penelitan yang sudah ada. Hal ini nantinya akan memperkaya literatur terkait budaya organisasi.

\section{Budaya Organisasi}

Istilah budaya organisasi sering kali disebut dengan budaya perusahaan ketika konsep ini dibawa kepada korporasi. Sementara sering juga budaya organisasi ini disebut dengan budaya kerja. Hal ini mempertimbangkan kaitan erat antara budaya organisasi dengan kinerja sumber daya manusia dari organisasi tersebut. Semakin kuat budaya organisasi bisa dikatakan bahwa dorongan untuk berprestasi dari sumber daya manusianya juga akan semakin besar. Pettgrew dalam Sobirin (2011) mengungkapkan bahwa budaya organisasi diartikan sebagai sebuah sistem makna yang dipahami dan diakui secara terbuka dan kolektif, yang berlaku untuk waktu dan kelompok tertentu.

Dari uraian di atas, nampak jelas terlihat bahwa budaya organisasi erat kaitannya dengan kesepakatan anggota organisasi terhadap norma-norma atau aturan bersama yang bertujuan untuk mengatasi permasalahan-permasalahan yang timbul dalam suatu organisasi. Dapat disimpulkan juga budaya organisasi merupakan seperangkat asumsi atau sistem keyakinan, nilai-nilai dan norma yang dianut oleh setiap anggota organisasi yang dijadikan sebagai pedoman membentuk dan mengarahkan 


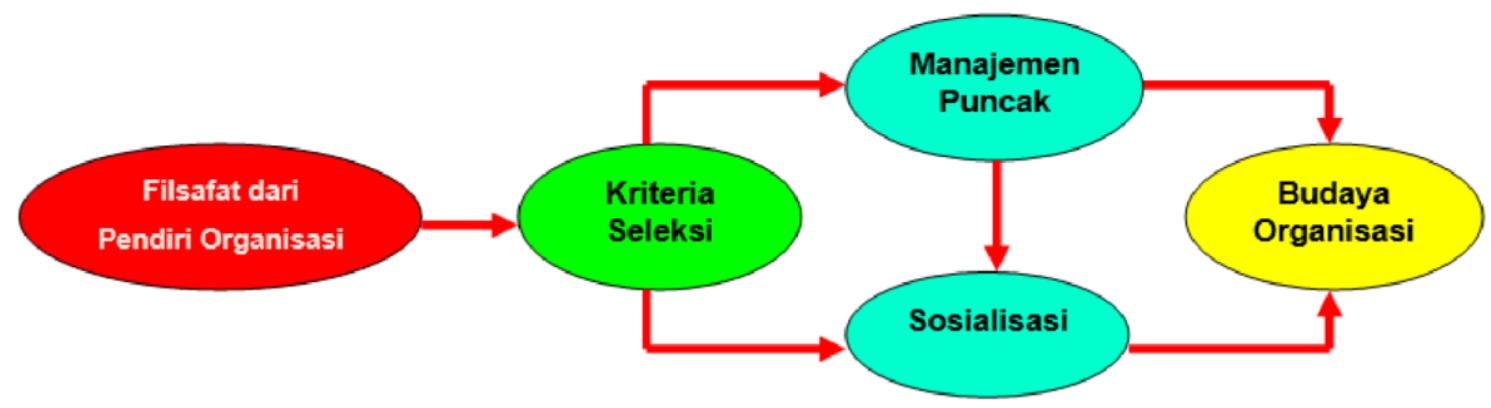

Gambar 1. Proses Terbentuknya Budaya Organisasi

Sumber: (Robbins, 2008)

perilaku dalam mengatasi masalah akibat adanya perubahan.

Menurut Robbins (2008), budaya organisasi memiliki beberapa indikator, sebagai berikut.

a. Inovasi dan pengambilan risiko: berkaitan dengan sejauh mana para anggota organisasi atau karyawan didorong untuk inovatif dan berani mengambil risiko.

b. Perhatian pada hal-hal detail: berkaitan dengan sejauh mana para anggota organisasi atau karyawan diharapkan mau memperlihatkan kecermatan, analisis dan perhatian terhadap hal-hal yang detail (rinci).

c. Berorientasi pada hasil: berkaitan dengan sejauh mana manajemen fokus pada hasil, bukan pada teknik dan proses yang digunakan untuk mendapatkan hasil tersebut.

d. Orientasi pada orang: berkaitan dengan sejauh mana keputusan manajemen memperhitungkan efek hasil kepada orang-orang di dalam organisasi tersebut.

e. Orientasi pada tim: berkaitan dengan sejauh mana kegiatan kerja organisasi dilaksanakan dalam tim-tim kerja, bukan pada individu-individu.

f. Agresivitas: sejauh mana orangorang dalam organisasi menunjukkan keagresifan dan kompetitif, bukannya bersantai.

g. Stabilitas: sejauh mana kegiatan organisasi menekankan dipertahankannya status quo sebagai lawan dari pertumbuhan atau inovasi

\section{Kinerja}

Kinerja menurut Suprihanto dalam Uno \& Lamatenggo (2012: 62): adalah prestasi kerja, yaitu hasil kerja seseorang karyawan selama periode tertentu dibandingkan dengan berbagai kemungkinan, misalnya standar, target, atau kriteria yang telah ditentukan lebih dahulu dan telah disepakati bersama.

Sementara menurut Bastian dalam Fahmi (2011: 2) kinerja merupakan gambaran mengenai tingkat pencapaian pelaksanaan suatu kegiatan atau program atau kebijaksanaan dalam mewujudkan sasaran, tujuan, misi, visi organisasi yang tertuang dalam perumusan skema strategis (strategic planning) suatu organisasi. 
Gambar 2.2. Kerangka Pemikiran

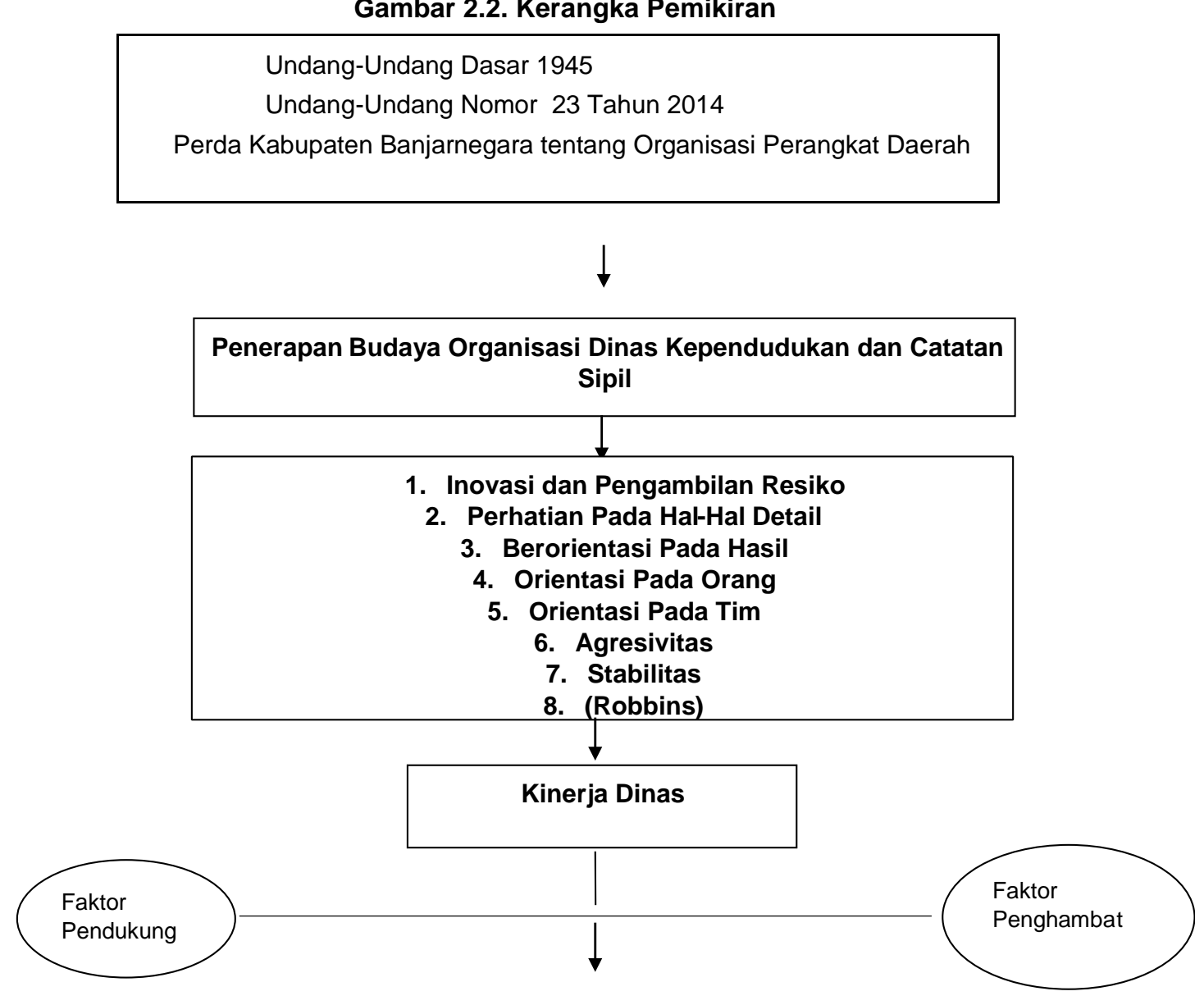

Pencapaian Tugas dan Fungsi Dinas Kependudukan dan Catatan Sipil

(Tertib Administrasi Kependudukan Bagi Seluruh Penduduk)

\section{METODE PENELITIAN}

\section{Desain Penelitian}

Pada penelitian ini, penulis menggunakan metode kualitatif dengan pendekatan induktif. Pendekatan induktif merupakan cara berpikir untuk memberikan alasan yang dimulai dari pernyataanpernyataan spesifik untuk menyusun suatu argumentasi yang bersifat umum (Nazir, 2011). Dengan demikian, pendekatan induktif dapat dipahami sebagai suatu cara dalam memecahkan suatu problematik, mulai dari kegiatan mencari fakta, nyata dan murni dari pengalaman

\section{Sumber Data}

Sumber data penelitian ini menggunakan sumber data sebagaimana diklasifikasikan oleh Arikunto (2012), yaitu.:

a. Person, yaitu sumber data berupa orang. Sumber data pada penelitian ini adalah aparat pada Dinas Kependudukan dan Catatan Sipil Kabupaten Banjarnegara, yaitu Kepala Dinas, Kepala Bidang Pencatatan sipil, Kepala seksi Kelahiran dan Kematian. 
b. Place, yaitu sumber data berupa tempat yang menyajikan tampilan berupa keadaan diam dan bergerak. Yang menjadi tempat ataupun lokasi penelitian ini adalah Dinas Kependudukan dan Catatan Sipil Kabupaten Banjarnegara.

c. Paper, yaitu sumber data yang menyajikan tanda-tanda berupa huruf, angka, gambar atau simbol-simbol lain yang diperoleh dari dokumentasi. Adapun sumber data dalam penelitian ini adalah berupa Undang-undang, Peraturan Pemerintah dan Peraturan Daerah yang berkaitan dengan kinerja Dinas Kependudukan dan Catatan Sipil dalam pelayanan pembuatan akta kelahiran di Kabupaten Banjarnegara. Fokus Penelitian

Tabel 1. Lingkup Penelitian

\begin{tabular}{|c|c|}
\hline Fokus Kajian & Aspek Kajian \\
\hline $\begin{array}{l}\text { Penerapan Budaya } \\
\text { Kerja }\end{array}$ & $\begin{array}{l}\text { 1. Inovasi dan } \\
\text { pengambilan risiko } \\
\text { 2. Perhatian terhadap } \\
\text { detail } \\
\text { 3. Orientasi pada } \\
\text { hasil } \\
\text { 4. Orientasi pada } \\
\text { manusia } \\
\text { 5. Orientasi pada tim } \\
\text { 6. Agresivitas } \\
\text { 7. Stabilitas }\end{array}$ \\
\hline $\begin{array}{l}\text { Faktorpenghambat } \\
\text { budaya organisasi } \\
\text { dalam meningkatkan } \\
\text { kinerja }\end{array}$ & $\begin{array}{l}\text { 1. Faktor kelemahan } \\
\text { 2. Faktor Ancaman }\end{array}$ \\
\hline $\begin{array}{l}\text { Upaya yang dilakukan } \\
\text { aparat dalam } \\
\text { mengatasi } \\
\text { hambatanhambatan }\end{array}$ & $\begin{array}{l}\text { 1. Internal Organisasi } \\
\text { 2. E k s t e r n a l } \\
\text { Organisasi }\end{array}$ \\
\hline
\end{tabular}

Sumber: Robbins, 2008 (diolah penulis)

\section{Teknik Pengumpulan Data dan Instrumen Penelitian}

Teknik pengumpulan data yang penulis gunakan untuk mendapatkan data, yaitu, dengan menggunakan metode wawancara dan dokumentasi.

\section{a. Wawancara}

Wawancara yang akan digunakan penulis adalah dengan pedoman wawancara semi terstruktur, di mana pelaksanaannya lebih bebas, oleh karena itu permasalahan yang ditemukan secara lebih terbuka melalui pendapat dan ideide dari pihak yang diwawancara. Jadi jawaban yang diperoleh diharapkan memiliki keterangan yang lengkap dan mendalam.

Cara menentukan partisipan dalam wawancara dengan menggunakan metode purposive sampling.

\section{b. Dokumentasi}

Menurut Arikunto (2010: 201), Dokumentasi adalah 'metode yang dilaksanakan oleh peneliti untuk meneliti benda-benda tertulis, seperti buku-buku, majalah, dokumen, peraturan-peraturan, notulen rapat, catatan harian, dan sebagainya.

\section{Teknik Penentuan Keabsahan Data}

Sebagai cara untuk menentukan keabsahan data dalam penelitian digunakan teknik triangulasi data. Teknik ini menggunakan sesuatu dari eksternal data itu guna mengecek dan membandingkan data tersebut (Moleong, 2009).

Lebih lanjut, triangulasi meliputi empat aspek, yakni: (1) triangulasi metode, (2) triangulasi antar-peneliti (jika penelitian dilakukan dengan kelompok), (3) triangulasi sumber data, dan (4) triangulasi teori ( Moleong, 2009). 


\section{Teknik Analisis Data}

Dalam menganalisis data penulis menggunakan tiga tahapan, yaitu Reduksi Data (Data Reduction), Penyajian Data (Display Data). dan Penarikan Simpulan Data.

\section{Lokasi dan Jadwal Penelitian}

Penelitian mengambil lokasi di Dinas Kependudukan dan Pencatatan Sipil Kabupaten Banjarnegara Provinsi Jawa Tengah.

\section{HASIL PENELITIAN DAN PEMBAHASAN}

\section{Sejarah Dinas Kependudukan dan Pencatatan Sipil Kabupaten Banjarnegara}

Lembaga Catatan Sipil di Indonesia merupakan kelanjutan dari Lembaga Catatan Sipil pada zaman Pemerintahan Belanda yang dikenal dengan nama

Bugerlijke Stand (BS), yaitu lembaga yang ditugasi untuk memelihara daftar-daftar atau catatan-catatan untuk pembuktian status atau peristiwa-peristiwa penting bagi Warga Negara seperti Kelahiran, Perkawinan, dan Kematian. Catatan Sipil adalah catatan yang menyangkut kedudukan hukum seseorang. Hal itu penting karena Indonesia adalah negara hukum sehingga setiap kedudukan Warga Negara harus jelas dan pasti karena setiap peristiwa akan membawa akibat hukum bagi kehidupan orang yang bersangkutan, orang lain atau pihak ketiga. Pencatatan yang dilakukan oleh Lembaga Catatan Sipil merupakan data-data tentang kependudukan yang dapat dijadikan bukti otentik sehingga kedudukan hukum seseorang menjadi jelas.

\section{Dinas Kependudukan dan Catatan Sipil Kabupaten Banjarnegara}

Keberadaan Disdukcapil kabupaten Banjarnegara berawal dari sebuah sub bagian di Sekretariat Daerah Kabupaten Banjarnegara, yaitu Sub Bagian Catatan Sipil pada 1992. Pada saat itu Sub Bagian Catatan Sipil masih berada di bawah Bagian Pemerintahan. Pada tahun 2001 bergabung dalam Dinas Kependudukan masuk pada Sub Dinas Kependudukan dan Catatan Sipil berkantor di Jl. A. Yani No. 7 Banjarnegara. Sub Bagian Kependudukan dan Catatan sipil berdiri sendiri menjadi Kantor Kependudukan dan Catatan Sipil pada 2004 berdasarkan Perda Nomor 24 Tahun 2003. Kemudian dengan adanya Perda Nomor 16 Tahun 2008 tentang Pembentukan Organisasi dan Tata Kerja Dinas-dinas Kabupaten Banjarnegara, Kantor tersebut berubah menjadi Dinas Kependudukan dan Pencatatan Sipil Kabupaten Banjarnegara yang terdiri dari Bidang Pencatatan Sipil, Bidang Pendaftaran Penduduk dan Pengelolaan Informasi Kependudukan.

Struktur organisasi ini ditetapkan berdasarkan Peraturan Bupati Banjarnegara Tahun 2016 tentang Kedudukan, Susunan Organisasi, Tugas dan Fungsi Serta Tata Kerja Dinas Kependudukan dan Pencatatan Sipil Kabupaten Banjarnegara.

\section{Kinerja Dinas}

Kinerja Dinas Kependudukan dan Pencatatan Sipil Kabupaten Banjarnegara sebagaimana dituangkan dalam Laporan Kinerja Instansi Pemerintah Dinas Dukcapil 2018 diklasifikasikan ke dalam dua sasaran dan lima indikator.

Sasaran pertama adalah meningkatnya kualitas pelayanan prima kepada masyarakat di bidang kependudukan dan pencatatan sipil. Pada sasaran ini terdiri dari dua indikator, yakni:

\section{Survei Kepuasan Masyarakat}

Apabila dibandingkan antara target dan realisasi kinerja tahun ini, pada indikator kinerja survei kepuasan masyarakat tercapai

Tabel 2 Survei Kepuasan Masyarakat 


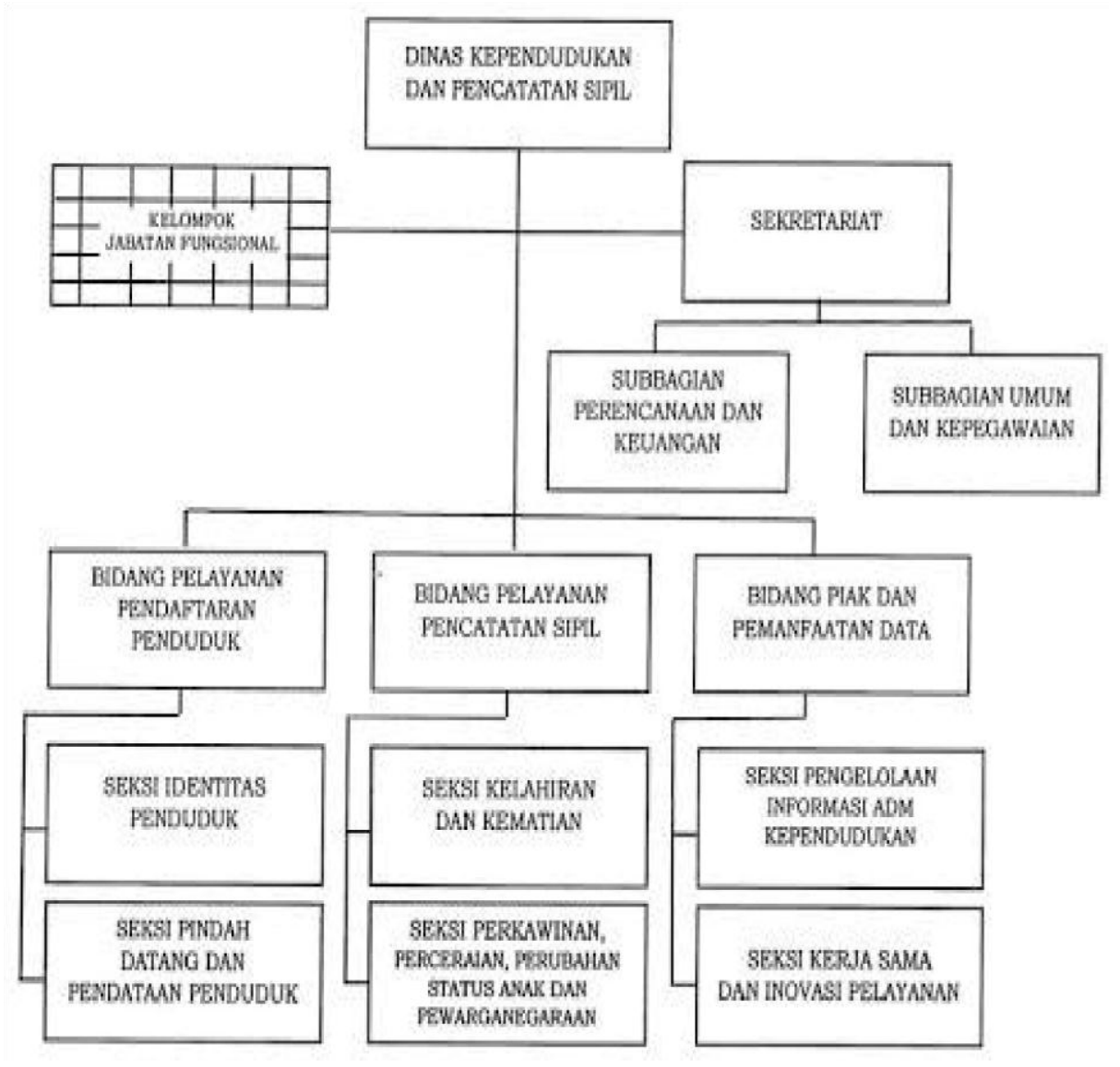

Gambar 3. SOTK Dinas Kependudukan dan Pencatatan Sipil Kabupaten Banjarnegara.

dengan nilai 81,60, dapat digambarkan sebagai berikut.

\begin{tabular}{|c|c|c|c|}
\hline $\begin{array}{c}\text { INDIKATOR } \\
\text { KINERJA }\end{array}$ & $\begin{array}{c}\text { TARGET } \\
2018 \\
\%\end{array}$ & $\begin{array}{c}\text { REALIS- } \\
\text { ASI } 2018 \\
\%\end{array}$ & $\begin{array}{c}\text { CAPA- } \\
\text { IAN (\%) }\end{array}$ \\
\hline $\begin{array}{l}\text { S u rve i } \\
\text { K e p u a s a n } \\
\text { Masyara kat }\end{array}$ & 78 & 81,60 & 104,61 \\
\hline
\end{tabular}

Sumber: LAKIP Dinas Dukcapil, 2018

Survei Kepuasan Masyarakat dilaksanakan sesuai dengan ketentuan dalam Peraturan Menteri Pendayagunaan Aparatur Negara dan Reformasi Birokrasi Nomor 14 Tahun 2017 tentang Pedoman Penyusunan Survei Kepuasan Masyarakat. Pedoman ini menggantikan pedoman sebelumnya dalam Permen-PAN RB No. 16 Tahun 2014 tentang
Pedoman Survei Kepuasan Masyarakat terhadap Penyelenggaraan Pelayanan Publik.

Dalam Permen-PAN No. 14 Tahun 2017 disebutkan bahwa SKM ini bertujuan untuk mengukur tingkat kepuasan masyarakat sebagai pengguna layanan dan meningkatkan kualitas penyelenggaraan pelayanan publik. Unsur-unsur yang menjadi fokus dalam pelaksanaan Survei Kepuasan Masyarakat terdiri dari sembilan unsur, di mana perolehan hasil survei di setiap unsur dapat dilihat dari tabel 3.

Sumber: LAKIP Dinas Dukcapil, 2018

Sementara hasil survei kepuasan masyarakat dari tahun ke tahun dapat dilihat pada Gambar 4: 
Vol. $12 \backslash$ No. 2\April 2020: 365-385

\begin{tabular}{|c|c|c|c|c|c|}
\hline NO & UNSUR PELAYANAN & $\begin{array}{l}\text { NILAI UNSUR } \\
\text { PELAYANAN }\end{array}$ & $\begin{array}{c}\text { KINERJA } \\
\text { UNSUR } \\
\text { PELAYANAN }\end{array}$ & ВОВОТ & $(3) *(5)$ \\
\hline 1 & Persyaratan Pelayanan & 3,24 & Baik & 0,111 & 0,36 \\
\hline 2 & $\begin{array}{l}\text { Sistem, mekanisme dan } \\
\text { prosedur }\end{array}$ & 3,15 & Baik & 0,111 & 0,35 \\
\hline 3 & Waktu Pelayanan & 2,90 & Baik & 0,111 & 0,32 \\
\hline 4 & Biaya/tarif pelayanan & 3,59 & Sangat Baik & 0,111 & 0,40 \\
\hline 5 & Produk layanan & 3,27 & Sangat Baik & 0,111 & 0,36 \\
\hline 6 & Kompetensi pelaksana & 3,28 & Sangat Baik & 0,111 & 0,36 \\
\hline 7 & Perilaku pelaksana & 3,43 & Sangat Baik & 0,111 & 0,38 \\
\hline 8 & $\begin{array}{l}\text { Penanganan } \\
\text { pengaduan, } \\
\text { saran, dan masukan }\end{array}$ & 3,33 & Sangat Baik & 0,111 & 0,37 \\
\hline 9 & Sarana dan prasarana & 3,22 & Baik & 0,111 & 0,36 \\
\hline \multicolumn{5}{|c|}{ Nilai Indeks } & 3,26 \\
\hline \multicolumn{5}{|c|}{ Nilai IKM } & 81,60 \\
\hline \multicolumn{5}{|c|}{ Mutu pelayanan } & A \\
\hline \multicolumn{5}{|c|}{ Kinerja unit pelayanan } & Sangat Baik \\
\hline
\end{tabular}

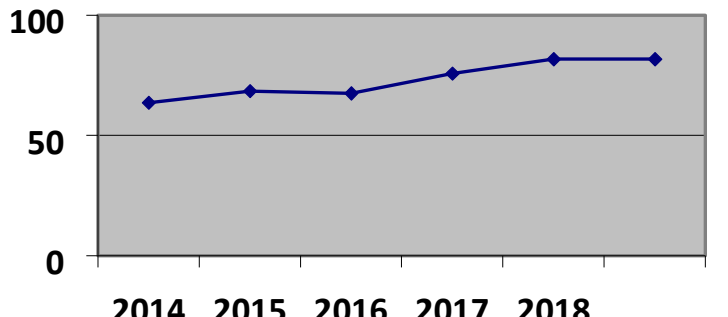

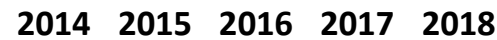

Gambar 4

Hasil survei kepuasan masyarakat dari tahun ke tahun

Sumber: LAKIP Dinas Dukcapil, 2018

Secara kuantitatif, terdapat kecenderungan (trend) fluktuatif dari tahun ketahun. Hal ini menggambarkan Dinas Kependudukan dan Pencatatan Sipil dari tahun ke tahun terjadi peningkatan kualitas pelayanan publik kepada masyarakat.

Apabila dibandingkan antara realisasi kinerja sampai dengan tahun ini dengan target RPJMD yang terdapat dalam dokumen perencanaan strategis organisasi, dapat digambarkan sebagai berikut.

Tabel 4

\begin{tabular}{|l|c|c|c|}
\hline \multicolumn{1}{|c|}{ INDIKATOR } & TARGET & $\begin{array}{c}\text { REALIS- } \\
\text { ASI 2018 } \\
2018 \\
\%\end{array}$ & $\begin{array}{c}\text { CAPAIAN } \\
(\%)\end{array}$ \\
\hline $\begin{array}{l}\text { Survei } \\
\text { Kepuasan } \\
\text { Masyarakat }\end{array}$ & 96 & 81,60 & 85 \\
\hline
\end{tabular}

Sumber: LAKIP Dinas Dukcapil, 2018

Indikator kinerja telah mencapai 85\% jika dibandingkan dengan target akhir RPJMD atau dapat dikatakan memuaskan. Keberhasilan indikator kinerja ini didukung/ 
disebabkan oleh beberapa hal sebagai berikut.

1. Peningkatan kinerja petugas pelayanan

2. Optimalisasi fungsi sarana dan prasarana administrasi perkantoran

3. Publikasi standar pelayanan kepada pengguna layanan sehingga pengguna layanan dapat memahami standar pelayanan untuk masing-masing jenis layanan.

Kendala yang dihadapi dalam pelaksanaan survei kepuasan masyarakat antara lain sebagai berikut.

1. Pelaksanaan survei dilakukan secara manual sehingga responden masih bisa dipengaruhi oleh pihak lain.

2. Komitmen pimpinan perangkat daerah masih kurang begitu peduli.

3. Hasil survei kepuasan masyarakat belum dijadikan umpan balik untuk peningkatan pelayanan publik.

Terhadap kendala tersebut langkah dan strategi yang akan dilakukan adalah dengan membangun aplikasi survei kepuasan masyarakat, menjadikan hasil survei sebagai dasar penganggaran.

Indikator kinerja survei kepuasan masyarakat dicapai dengan melaksanakan empat program berikut.

1. Program pelayanan administrasi perkantoran

2. Program peningkatan sarana dan prasarana aparatur

3. Program peningkatan kapasitas sumber daya aparatur

4. Program mengintensifkan penanganan pengaduan masyarakat;
Output kegiatan ini berupa nilai survei kepuasan masyarakat.

\section{Nilai Akuntabilitas Kinerja Instansi Pemerintah (SAKIP)}

Apabila dibandingkan antara target dan realisasi kinerja tahun ini, pada indikator kinerja Nilai Akuntabilitas Kinerja Instansi Pemerintah (SAKIP) sudah tercapai dengan nilai $B$, dapat digambarkan sebagai berikut.

Tabel 5

\begin{tabular}{|c|c|c|c|}
\hline $\begin{array}{c}\text { INDIKATOR } \\
\text { KINERJA }\end{array}$ & $\begin{array}{c}\text { TARGET } \\
2018\end{array}$ & $\begin{array}{l}\text { REALIS- } \\
\text { ASI } 2018\end{array}$ & $\begin{array}{l}\text { CAPA- } \\
\text { IAN (\%) }\end{array}$ \\
\hline \begin{tabular}{l}
$\mathrm{N} \quad \mathrm{i}$ \\
$\quad \mathrm{l}$ \\
\multicolumn{1}{c}{$\mathrm{a}$} \\
\multicolumn{1}{c}{$\mathrm{i}$} \\
Akuntabilitas \\
K in e r ja I n \\
s t a n s i \\
Pemerintah \\
(SAKIP)
\end{tabular} & CC & B & $\begin{array}{l}\text { Melebihi } \\
\text { Target }\end{array}$ \\
\hline
\end{tabular}

Sumber: LAKIP Dinas Dukcapil, 2018

Dalam rangka mendorong terciptanya akuntabilitas kinerja instansi pemerintah sebagai salah satu prasyarat untuk terciptanya pemerintah yang baik dan terpercaya. Maka Dinas Kependudukan dan Pencatatan Sipil mengukur indikator kinerja melalui penilaian Akuntabilitas Kinerja Instansi Pemerintah (SAKIP).

Nilai tersebut diperoleh dari hasil evaluasi SAKIP oleh Inspektorat Kabupaten Banjarnegara yang berpedoman pada Peraturan Menteri Pendayagunaan Aparatur Negara dan Reformasi Birokrasi No.12 Tahun 2015, dengan beberapa komponen penilaian yang meliputi: Perencanaan Kinerja; Pengukuran Kinerja; Pelaporan Kinerja; Evaluasi internal dan Pencapaian Kinerja. Nilai tersebut merupakan akumulasi penilaian terhadap seluruh komponen manajemen kinerja yang dievaluasi. 
Sebagaimana dalam Laporan Hasil Evaluasi Akuntabilitas Kinerja Instansi Pemerintah Tahun 2017 Nomor: 700/12/LHE/2018 tanggal 27 September 2018, Inspektorat Kabupaten Banjarnegara ditugaskan untuk melaksanakan evaluasi atas Akuntabilitas Kinerja Instansi Pemerintah pada Dinas Kependudukan dan Pencatatan Sipil pada 2017.

Apabila dibandingkan antara realisasi kinerja serta capaian kinerja tahun ini dengan tahun lalu, yaitu 2016 dan 2017, dapat digambarkan sebagai berikut.

Tabel 6

\begin{tabular}{|c|c|c|c|c|c|}
\hline \multirow{2}{*}{$\begin{array}{c}\text { INDIKATOR } \\
\text { KINERJA }\end{array}$} & \multicolumn{5}{|c|}{ REALISASI } \\
\hline & 2014 & 2015 & 2016 & 2017 & 2018 \\
\hline 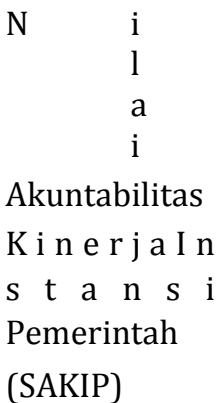 & - & - & $\mathrm{C}$ & $\mathrm{CC}$ & B \\
\hline
\end{tabular}

Sumber: LAKIP Dinas Dukcapil, 2018

Secara kuantitatif, terdapat kecenderungan (trend) fluktuatif dari tahun ke tahun. Dari data di atas, maka dapat disimpulkan bahwa realisasi atas target yang telah ditetapkan capaiannya meningkat sampai pada level B. Di mana pada sebelumnya, yaitu evaluasi AKIP tahun 2017 perolehan nilai SAKIP hanya 52,88 dengan kategori CC atau cukup menjadi 67,61 dengan kategori B atau Baik, pada evaluasi AKIP 2018.

Sasaran kedua adalah meningkatnya tertib administrasi kependudukan masyarakat Banjarnegara. Analisis capaian kinerja pada sasaran 2, Dinas Kependudukan dan Pencatatan Sipil Kabupaten Banjarnegara yang dijabarkan diukur dengan tiga indikator kinerja berikut.
1. Persentase penyelesaian administrasi kependudukan (adminduk)

2. Persentase pembangunan dan pengoperasian SIAK secara terpadu

3. Persentase pendayagunaan sistem informasi kependudukan yang dapat diakses masyarakat

Adapun pencapaian target dari masingmasing indikator kinerja dapat diuraikan sebagai berikut.

\section{Persentase penyelesaian administrasi kependudukan (adminduk)}

Apabila dibandingkan antara target dan realisasi kinerja tahun ini, pada indikator kinerja Persentase penyelesaian administrasi kependudukan (adminduk) tercapai sebesar $75,56 \%$, dapat digambarkan sebagai berikut.

Tabel 7

\begin{tabular}{|c|c|c|c|}
\hline \multicolumn{1}{|c|}{ INDIKATOR } & TARGET & REALIS- & CAPAIAN \\
KINERJA & $\begin{array}{c}2018 \\
\%\end{array}$ & $\begin{array}{c}\text { ASI 2018 } \\
\%\end{array}$ & \\
\hline & & ) \\
\hline $\begin{array}{l}\text { P e r s e n t a s e } \\
\text { penyelesaian } \\
\text { administrasi } \\
\text { kependudukan } \\
\text { (Adminduk ) }\end{array}$ & 92 & 75,56 & 82,34 \\
\hline
\end{tabular}

Sumber: LAKIP Dinas Dukcapil, 2018

Realisasi sebesar 75,56 dihitung dari ratarata persentase perhitungan kepemilikan KTP elektronik, kepemilikan kartu keluarga, kepemilikan akta kelahiran 0-18 tahun, dan percetakan akta-akta pencatatan sipil selain akta kelahiran. Berdasarkan tabel di atas dapat dilihat bahwa pada Tahun 2018, prosentase penyelesaian administrasi kependudukan (adminduk) belum tercapai sesuai target yang ditetapkan. Dikarenakan kegiatan percetakan Kartu Identitas Anak (KIA) belum dilaksanakan sesuai target yang telah ditetapkan. 
Sebagai informasi bahwa dalam rangka peningkatan pelayanan Administrasi Kependudukan sejalan dengan tuntutan pelayanan Administrasi Kependudukan yang profesional, memenuhi standar teknologi informasi, dinamis, tertib, dan tidak diskriminatif dalam pencapaian standar pelayanan minimal menuju pelayanan prima yang menyeluruh untuk mengatasi permasalahan kependudukan, perlu diukur dengan indikator kinerja secara berkala. Indikator yang dimaksud adalah indikator yang mengukur kinerja tentang Administrasi Kependudukan (adminduk).

Sesuai UU 23 Tahun 2006 tentang Administrasi Kependudukan yang dimaksud Administrasi Kependudukan adalah rangkaian kegiatan penataan dan penertiban dalam penerbitan dokumen dan Data Kependudukan melalui Pendaftaran Penduduk, Pencatatan Sipil, pengelolaan informasi Administrasi Kependudukan serta pendayagunaan hasilnya untuk pelayanan publik dan pembangunan sektor lain. Administrasi kependudukan terdiri dari kepengurusan KTP elektronik, kartu keluarga, akta kelahiran dan akta-akta pencatatan sipil lainnya selain akta kelahiran.

\section{Persentase pembangunan dan pengoperasian SIAK secara terpadu}

Apabila dibandingkan antara target dan realisasi kinerja tahun ini, pada indikator kinerja Persentase pembangunan dan pengoperasian SIAK secara terpadu tercapai sebesar 100, dapat digambarkan sebagai berikut.

Tabel 8

\begin{tabular}{|c|c|c|c|}
\hline $\begin{array}{c}\text { INDIKATOR } \\
\text { KINERJA }\end{array}$ & $\begin{array}{c}\text { TAR- } \\
\text { GET \% }\end{array}$ & $\begin{array}{c}\text { REAL- } \\
\text { ISASI \% }\end{array}$ & $\begin{array}{c}\text { CAPA- } \\
\text { IAN (\%) }\end{array}$ \\
\hline
\end{tabular}

\begin{tabular}{|l|l|l|l|}
\hline $\begin{array}{l}\text { Persentase } \\
\text { pembangunan }\end{array}$ & 100 & 100 & 100 \\
dan & & & \\
pengoperasian & & & \\
$\begin{array}{l}\text { SIAK secara } \\
\text { terpadu }\end{array}$ & & & \\
\hline
\end{tabular}

Sumber: LAKIP Dinas Dukcapil, 2018

Pencapaian itu diperoleh 100 \% karena dalam rangka memberikan pelayanan dokumen adminduk, jaringan SIAK berperan utama dalam membantu berbagai pekerjaan mengenai pendaftaran kependudukan yang sesuai dengan standar yang diperlukan bahkan pemerintah merumuskan sebuah kebijakan baru, yaitu Sistem Informasi Administrasi Kependudukan (SIAK) dengan perkembangan versi yang setiap tahun mengalami peningkatan. SIAK merupakan suatu sistem informasi berbasis web yang disusun berdasarkan prosedur-prosedur dan memakai standardisasi khusus yang bertujuan menata sistem administrasi di bidang kependudukan sehingga tercapai tertib administrasi dan juga membantu bagi petugas di jajaran Pemerintah Daerah khususnya Dinas Kependudukan dan

Pencatatan Sipil di dalam menyelenggarakan layanan kependudukan dan Pencatatan

Sipil.

Apabila dibandingkan antara realisasi kinerja serta capaian kinerja tahun ini dengan tahun lalu dan beberapa tahun terakhir, dapat digambarkan sebagai berikut.

Tabel 9

\begin{tabular}{|c|c|c|c|c|c|}
\hline \multirow{2}{*}{$\begin{array}{c}\text { INDIKATOR } \\
\text { KINERJA }\end{array}$} & 2014 & 2015 & 2016 & 2017 & 2018 \\
\cline { 2 - 6 } & & & & & \\
\hline $\begin{array}{c}\text { Persentase } \\
\text { pembangunan } \\
\text { dan pengo- } \\
\text { p e r a s i a n } \\
\text { SIAK secar }\end{array}$ & 100 & 100 & 100 & 100 & 100 \\
a terpadu & & & & & \\
\hline
\end{tabular}


Sumber: LAKIP Dinas Dukcapil, 2018

Apabila dibandingkan antar target dan realisasi pada -tahun sebelumnya dalam penyelenggaraan pemerintahan di bidang Pengelolaan Informasi Administrasi KependudukaN (PIAK) setiap tahun dapat dikatakan berhasil 100\% karena pengelolaan SIAK dilakukan secara continue dengan anggaran yang cukup.

Apabila dibandingkan antara realisasi kinerja sampai dengan tahun ini dengan target jangka menengah yang terdapat dalam dokumen perencanaan strategis organisasi, dapat digambarkan sebagai berikut.

Tabel 10

\begin{tabular}{|c|c|c|c|}
\hline $\begin{array}{c}\text { INDIKATOR } \\
\text { KINERJA }\end{array}$ & $\begin{array}{c}\text { TARGET } \\
2022 \\
\%\end{array}$ & $\begin{array}{c}\text { REALIS- } \\
\text { ASI } 2018 \\
\%\end{array}$ & $\begin{array}{c}\text { CAPAIAN } \\
(\%)\end{array}$ \\
\hline $\begin{array}{l}\text { Persentase } \\
\text { pembangunan } \\
\text { dan } \\
\text { pengoperasian } \\
\text { SIAK secara } \\
\text { terpadu }\end{array}$ & 100 & 100 & 100 \\
\hline
\end{tabular}

Sumber: LAKIP Dinas Dukcapil, 2018

Realisasi kinerja sampai dengan tahun ini dengan target jangka menengah telah mencapai $100 \%$, karena perkembangan sistem informasi administrasi kependudukan selalu di upgrade mengikuti perubahan di pusat.

\section{Persentase pendayagunaan sistem informasi kependudukan yang dapat diakses masyarakat}

Apabila dibandingkan antara target dan realisasi kinerja tahun ini, pada indikator kinerja Persentase pendayagunaan sistem informasi kependudukan yang dapat diakses masyarakat tercapai 100, dapat digambarkan sebagai berikut.

Tabel 11

\begin{tabular}{|l|c|c|c|}
\hline \multicolumn{1}{|c|}{ INDIKATOR } & TARGE & REALIS & CAPAIA \\
$\mathrm{T}$ & \multicolumn{1}{c|}{ N (\%) } \\
$\%$ & ASI & \\
$\%$ & 100 & 100 \\
\hline $\begin{array}{l}\text { Persentase } \\
\text { pendayagunaa } \\
\mathrm{n} \\
\text { sistem } \\
\text { informasi } \\
\text { kependuduka } \\
\mathrm{n} \text { yang dapat } \\
\text { diakses } \\
\text { masyarakat }\end{array}$ & 100 & & \\
\hline
\end{tabular}

Sumber: LAKIP Dinas Dukcapil, 2018

Indikator ini mencapai $100 \%$ sesuai target yang telah ditetapkan karena meningkatnya pelayanan publik pada masyarakat termasuk menyediakan layanan akses informasi seputar kependudukan kepada masyarakat, pendayagunaan sistem informasi kependudukan yang dapat diakses masyarakat berjalan dengan baik.

Apabila dibandingkan antara realisasi kinerja serta capaian kinerja tahun ini dengan tahun lalu dan beberapa tahun terakhir, dapat digambarkan sebagai berikut.

Tabel 12

\begin{tabular}{|l|l|l|l|l|l|}
\hline \multirow{2}{*}{$\begin{array}{l}\text { INDIKATOR } \\
\text { KINERJA }\end{array}$} & \multicolumn{5}{|c|}{ REALISASI } \\
\cline { 2 - 6 } & 2014 & 2015 & 2016 & 2017 & 2018 \\
\hline $\begin{array}{l}\text { Persentase } \\
\text { pendayagunaan } \\
\text { sistem in for m } \\
\text { a s i } \\
\text { kependudukan } \\
\text { yang diakses } \\
\text { dapat } \\
\text { masya- } \\
\text { rakat }\end{array}$ & 100 & 100 & 100 & 100 & 100 \\
\hline
\end{tabular}

Sumber: LAKIP Dinas Dukcapil, 2018

Secara kuantitatif, terdapat kecenderungan (trend) meningkat apabila dibandingkan dengan beberapa tahun yang lalu dalam penyelenggaraan pemerintahan di bidang pelayanan akses informasi kependudukan kepada publik setiap tahun 
dapat dikatakan berhasil 100\% karena pengelolaan sistem informasi kependudukan dilakukan secara continue dengan anggaran yang cukup.

Tabel 13

\begin{tabular}{|c|c|c|c|}
\hline $\begin{array}{l}\text { INDIKATOR } \\
\text { KINERJA }\end{array}$ & $\begin{array}{c}\text { TAR- } \\
\text { GET \% }\end{array}$ & $\begin{array}{l}\text { REAL- } \\
\text { ISASI \% }\end{array}$ & $\begin{array}{l}\text { CAPA- } \\
\text { IAN (\%) }\end{array}$ \\
\hline $\begin{array}{l}\text { Persentase } \\
\text { pendayagunaan } \\
\text { sistem informasi } \\
\text { kependuduk an } \\
\text { yang dapat } \\
\text { diakses masya- } \\
\text { rakat }\end{array}$ & 100 & 100 & 100 \\
\hline
\end{tabular}

Sumber: LAKIP Dinas Dukcapil, 2018

Tabel 13 di atas membandingkan antara realisasi kinerja sampai dengan tahun ini dengan target jangka menengah yang terdapat dalam dokumen perencanaan strategis organisasi.

Berdasar tabel di atas indikator Persentase pendayagunaan sistem informasi kependudukan yang dapat diakses masyarakat jika dibandingkan dengan target RPJMD sudah mencapai $100 \%$ hal ini dikarenakan kerja sama dan koordinasi yang baik antar personel yang menangani data dan sistem akses kependudukan untuk masyarakat.

\section{HASIL PENELITIAN DAN PEMBAHASAN}

\section{Penerapan Budaya Organisasi}

Dalam penelitian ini, penulis menilai penerapan budaya organisasi di Dinas Kependudukan dan Catatan Sipil Kabupaten Banjarnegara dengan mengacu pada teori dari Robbins. Menurut Robbins, budaya organisasi meliputi tujuh aspek yang akan dijabarkan di bawah ini:

\section{Inovasi dan Pengambilan Resiko}

Hasil penelitian oleh penulis menunjukkan bahwa secara umum, dari informan, menyampaikan bahwa mereka siap mengambil risiko dalam melakukan pekerjaan yang menjadi tanggung jawabnya. Mereka menyatakan bahwa sudah menjadi satu kesatuan yang melekat antara risiko dengan pekerjaan. Lebih lanjut, ada delegasi kewenangan yang sangat terlihat, sehingga memang ada kepercayaan penuh dari pimpinan terhadap bawahan dalam penyelesaian pekerjaan.

Kepala seksi identitas penduduk menyampaikan bahwa:

"Di sini bawahan diberi keleluasaan dalam menyelesaikan pekerjaan. Tidak terlalu ribet dalam hal hierarki. Jadi kita enak kerjanya tidak terlalu kaku".

\section{Perhatian terhadap Detail}

Dalam kaitannya dengan aspek yang satu ini, terlihat bahwa secara keseluruhan dinas telah memiliki target serta pembagian tugas yang sangat baik. Hal ini membantu para pekerja dalam menyelesaikan apa yang menjadi tugas dan kewajibannya. Adanya visi misi serta target kinerja tahunan menjadikan kejelasan bagi pekerja terkait apa yang harus mereka kerjakan. Hal ini termasuk juga adalah arahan yang jelas dari pimpinan baik yang tertulis maupun tidak tertulis. Dinas Kependudukan dan Catatan Sipil setiap hari mengawali kegiatan dengan apel pagi. Di dalam apel pagi ini disampaikan kebijakan dan arahan baik yang sifatnya rutin maupun kegiatan incidental serta kebijakan strategis dari pimpinan dinas maupun pimpinan kabupaten yang terkait dengan administrasi kependudukan. Selain itu, adanya rapat rutin dan rapat evaluasi selalu mampu menjadi media yang baik dalam penyamaan persepsi serta arah tujuan pelaksanaan pekerjaan. Adanya evaluasi juga menuntut pegawai untuk selalu menyelesaikan pekerjaan dengan akurat sesuai target. 


\section{Orientasi Hasil}

Dinas Kependudukan dan Catatan Sipil Kabupaten Banjarnegara selama ini selalu mengutamakan hasil kerja yang optimal. Hal ini terlihat dari bagaimana dinas selalu berupaya meningkatkan kinerjanya (terlihat pada poin kinerja). Upaya sebagaimana disampaikan di poin sebelumnya dengan sistem jemput bola adalah indikasi bagaimana dinas telah berupaya menyusun strategi untuk mendapatkan hasil yang maksimal dengan cara yang efektif. dan memang terbukti bahwa terjadi peningkatan kinerja dinas setelah diterapkan sistem jemput bola itu. Selain itu, di tengah keterbatasan dukungan anggaran, dinas berupaya mengutamakan pelayanan dibanding fasilitas untuk pejabat. Salah satunya kegiatan jemput bola yang diimplementasikan sering kali menggunakan kendaraan dinas dari pejabat dikarenakan kendaraan operasional yang tidak memadai. Bahkan untuk daerah-daerah yang tidak memungkinkan menggunakan mobil, petugas rela menggunakan kendaraan roda dua pribadinya.

\section{Orientasi Individu}

Kondisi yang disampaikan pada poin sebelumnya juga mengindikasikan bagaimana dinas memiliki orientasi pada individu. Dinas, tidak membiarkan pegawainya bekerja sendiri tanpa dukungan dari instansi. Penyediaan bahan bakar dan dukungan trasnportasi lainnya menunjukkan perhatian yang diberikan kepada pegawai dinas. Di sisi lain, kesediaan pegawai menggunakan kendaraan pribadi menunjukkan bahwa pegawai berusaha menyelesaikan pekerjaan dengan sungguh-sungguh. Selain itu, ada kesadaran penuh dari pegawai bahwa kinerja individu akan memberikan dampak pada kinerja dinas secara lebih luas.

\section{Orientasi terhadap Tim}

Orientasi terhadap tim di lingkungan dinas Kependudukan dan Catatan Sipil Kabupaten Banjarnegara tercermin dari kuatnya kerja sama antar pegawai. Salah satunya terlihat dari bagaimana pelaksanaan pelayanan terutama ketika proses "jemput bola" dilaksanakan. Tim yang turun ke lapangan mampu bekerja dengan baik hanya karena mereka bekerja secara tim bukan hanya fokus pada individu. Selain itu, kejelasan proses komunikasi dan koordinasi memudahkan kerja tim. Begitu juga apabila ada permasalahan, solusi selalu dipikirkan bersama yang melibatkan semua pihak, mulai dari pimpinan sampai dengan staf.

\section{F. Agresivitas}

Sementara, pada poin agresivitas, di satu sisi pegawai menyatakan bahwa mereka akan melakukan pekerjaan yang memang menjadi tugas pokoknya. Mereka menyampaikan bahwa mereka tidak akan menyelesaikan tugas lain yang bukan menjadi tugas pokoknya apabila tidak diminta oleh pimpinan atau rekan kerjanya. Lebih lanjut, instansi hanya memiliki SOP tetapi tidak memiliki aturan yang mengatur tentang apa yang boleh dan tidak boleh dilakukan di luar kegiatan yang berkenaan dengan pekerjaan.

\section{Stabilitas}

Dinas Kependudukan dan Catatan Sipil menekankan bahwa semua pegawai adalah satu keluarga. Hal ini menjadikan adanya rasa saling memiliki dan berdampak pada perspektif pegawai. Mereka merasa bahwa mereka bukanlah alat yang dipergunakan oleh pimpinan ataupun dinas, sehingga pada akhirnya pegawai merasa nyaman bekerja di dinas. Selain itu, dinas sering 
mengadakan family gathering tiap akhir tahun meskipun dalam skala sederhana.

\section{Faktor yang Memengaruhi Penerapan Budaya Organisasi}

Hasil penelitian menggunakan teori Robbins menunjukkan terimplementasikannya budaya kerja dengan baik di lingkungan dinas terkait. Ada beberapa pendukung kuatnya budaya organisasi di lingkungan dinas.

a. Ukuran organisasi dinas yang tidak terlalu besar. Hal ini berdampak pada hubungan yang lebih dekat satu sama lain di dinas.

b. Dinas ini sudah berdiri sejak lama. Hal ini menyebabkan budaya organisasi yang sudah tertanam dalam waktu yang relatif panjang.

c. Perputaran pegawai di lingkup dinas juga tidak terlalu sering dilaksanakan. Hal ini berpengaruh pada kedekatan antar pegawai dan rasa saling memiliki. Di sisi lain, perputaran pegawai tetap dilaksanakan untuk menjaga antusiasme dan semangat kerja serta motivasi kerja guna menghindari kebosanan.

d. Pemberian contoh.

Penerapan budaya merupakan proses yang melibatkan seluruh organisasi, tetapi harus dimulai dari atas. Setiap anggota perlu secara aktif mengejar tujuan yang sama, atau inisiatif tidak akan bertahan. Seperti yang disampaikan oleh kepala dinas, yakni:

"Jika Anda tidak memimpin dengan memberi contoh, Anda tidak bisa mengharapkan orang lain melakukan

pekerjaan itu."

e. Budaya organisasi menjadi strategi melalui eksekusi.

Eksekusi adalah cara memanfaatkan kekuatan organisasi untuk benar-benar mewujudkan strategi itu. Semakin selaras budaya, semakin mudah transisi strategi dari rencana ke tindakan.

f. Melibatkan setiap karyawan.

Kepala dinas dalam interview-nya menyatakan bahwa "salah satu pelajaran pertama yang saya pelajari adalah bahwa setiap orang terlibat dalam budaya, termasuk saya." Karena budaya dibangun berdasarkan tindakan dan sikap setiap orang yang berpartisipasi di dalamnya, seluruh organisasi harus secara aktif bekerja bersama untuk mewujudkannya.

Akan tetapi kepala Dinas Kependudukan dan Pencatatan Sipil lebih memilih menyebut hal tersebut sebagai tantangan daripada hambatan. Hal tersebut di antaranya sebagai berikut.

a. Mempertahankan budaya organisasi. Tantangan utama bagi organisasi mana pun adalah mempertahankan budaya organisasi yang sehat. Adalah tindakan pegawai sendiri yang mencerminkan budaya organisasi, dan sangat penting untuk tetap menjadi elemen pemersatu. Mempertahankan budaya organisasi akan memerlukan tingkat keterlibatan pegawai. Lebih baik lagi, jika ada kesesuaian yang nyata antara nilai-nilai organisasi dan nilai-nilai anggotanya, hal ini akan berdampak pada peningkatan signifikan dalam keseluruhan tingkat kepuasan kerja.

b. Memperkuatnya setiap saat. Budaya organisasi juga harus selalu diwakili di seluruh organisasi. Nilai-nilai kita, etika, dan bahkan lingkungan kerja umum harus hadir dan konsisten setiap hari. Budaya organisasi haruslah nonsporadis agar memungkinkan kita untuk benarbenar merasa seperti kita bisa menjadi diri kita sendiri.

c. Libatkan semua anggota tim. Budaya organisasi harus melibatkan semua pegawai. Itu bahkan dapat muncul dan 
dibangun dari tim, daripada memaksakannya pada mereka oleh manajemen. Budaya perlu diintegrasikan dengan cara alami untuk memastikan semua orang merasa mereka adalah bagian dari proses. Mutasi pegawai walaupun sampai saat ini tidak berdampak negatif tetapi tidak menutup kemungkinan ke depannya bisa berdampak buruk. Kebahagiaan di tempat kerja adalah konsep yang lebih besar daripada keterlibatan; ini tentang menyediakan sumber daya yang dibutuhkan individu untuk mendukung diri mereka sendiri dan mengembangkan keterlibatan mereka.

Pegawai harus menjadi bagian dari proses itu. Anggota organisasi harus merasa terlibat dan merangkul gaya hidup budaya. Sangat penting untuk keberhasilannya agar setiap orang bergerak ke arah yang sama; karena itu pentingnya mengoptimalkannya secara terus-menerus dengan menggunakan seluruh tim.

\section{Upaya Dinas dalam Penerapan Budaya Organisasi}

Mengingat pentingnya dan juga hubungan antara budaya organisasi dengan kinerja dari Dinas, maka Dinas Kependudukan dan Pencatatan Sipil Kabupaten Banjarnegara melakukan beberapa upaya, di antaranya:

a. Melakukan internalisasi budaya organisasi melalui kegiatan-kegiatan bersama yang melibatkan semua pegawai. Salah satunya adalah adanya kegiatan gathering yang mengundang seluruh pegawai mulai dari staf sampai dengan pimpinan bahkan pegawai pendukung seperti petugas kebersihan.

b. Memperkenalkan budaya organisasi dan nilai-nilai organisasi kepada pegawai baru yang masuk ke Dinas. c. Penekanan kepada setiap pimpinan unit untuk dapat memberikan teladan dan contoh kepada pegawai yang lain dalam pelaksanaan kinerja.

d. Memecahkan setiap permasalahan (problem solving) dengan melibatkan semua elemen organisasi, agar melahirkan suatu terobosan yang tidak berkutat hanya pada satu sudut pandang saja, dan satu bidang keilmuan, tetapi juga dari multi disiplin ilmu, sehingga hasil pemecahan masalah yang tercipta lebih berkualitas dan memiliki impact positif yang besar terhadap penyelesaian masalah tersebut;

e. Para pimpinan di dalam organisasi, seyogianya dapat menjadi pioner sekaligus mendorong para anggota/ staf unit kerjanya untuk dapat berinovasi dan berpikir out of the box dalam menyelesaikan permasalahan seperti yang dijelaskan pada huruf d., dikarenakan perkembangan zaman yang kian maju, serta iklim kerja yang dinamis, diperlukan pemikiranpemikiran baru yang tidak hanya dilahirkan dari pemikiran satu orang tapi juga banyak orang di dalam organisasi tersebut. Inovasi dan perubahanperubahan tersebut juga tetap mengedepankan prinsip sustainability dan berbasis leading advantage;

f. Menjalin Komunikasi yang konstan dari pimpinan kepada semua elemen organisasi baik dari tingkat top sampai dengan low manager. Para pemimpin sering membuat mistakes (kesalahan) dengan membayangkan bahwa jika mereka menyampaikan pesan yang kuat dari perubahan pada awal inisiatif, maka orang akan mengerti apa yang harus dilakukan. Namun, Justru perubahan yang kuat dan berkelanjutan seperti pada poin e. Memerlukan komunikasi yang konstan, semakin banyak jenis komunikasi yang digunakan, semakin 
efektif pula upaya perubahan dan inovasi tersebut berjalan;

g. Melakukan evaluasi secara rutin dengan cara mengukur tingkat keberhasilan program. Para pemimpin di Disdukcapil Banjarnegara dapat meluangkan waktu untuk mencari tahu apa yang telah berhasil dikerjakan dan apa yang belum berhasil dicapai. Sehingga, mereka bisa melakukan penyesuaian langkah yang harus ditempuh ke depannya;

h. Memanfaatkan solusi formal, Membujuk orang untuk mengubah perilaku mereka tidak akan cukup dengan transformasi kecil-kecilan, seperti elemen struktur formal, sistem penghargaan, pelatihan, dan pengembangan saja. Justru faktanya banyak organisasi yang gagal di sini. Jadi cobalah untuk membuat solusi yang lebih kuat, seperti program mentoring. Sehingga, dengan program Mentoring ini memungkinkan para pemimpin perusahaan memberlakukan perubahan kebijakan secara menyeluruh dan melakukan persamaan persepsi secara holistik serta terpadu;

i. Solusi formal juga harus diikuti dengan solusi informal, dalam rangka meningkatkan budaya organisasi, solusi informal juga perlu diberikan, seperti dengan meminta setiap anggota untuk bertanggung jawab atas kualitas, dan dengan merayakan dan menghargai sebuah upaya perbaikan;

j. Mengajak pemimpin di luar lini, untuk berpartisipasi memimpin ke arah yang lebih baik. Contohnya adalah kepala dinas dapat mengajak para penata muda yang disukai oleh staf lain dan baik kinerjanya untuk ikut membantu memimpin organisasi menuju perubahan, Kepala Bidang mengajak para kepala seksi atau staf di bawahnya yang menjadi panutan anggota organisasi lain untuk menjadi pasukan khusus membantu Kepala bidang tersebut memimpin unit yang dipimpinnya.

\section{SIMPULAN}

\section{a. Penerapan Budaya Organisasi.}

Berdasarkan hasil penelitian dapat diambil simpulan bahwa pada dinas Kependudukan dan Pencatatan

Sipil Kabupaten Banjarnegara telah diimplementasikan budaya organisasi, namun budaya organisasi yang dilaksanakan masih terbatas pada kegiatan-kegiatan sederhana yang tidak ber-impact banyak terhadap keberlangsungan organisasi, adakalanya cara-cara yang digunakan cenderung tidak efektif meningkatkan kualitas kerja sel-sel organisasi, minim inovasi/terobosan, sehingga terjadi ketidaksesuaian eksekusi di lapangan dengan perkembangan zaman yang ada. Komunikasi antara bawahan dan pimpinan berlangsung secara monoton, tidak ada sebuah terobosan baru untuk dapat mengubah sistem komunikasi tersebut supaya berlangsung efektif dan efisien, semua berjalan kaku, dan sebatas mengikuti apa yang sudah ada, adakalanya komunikasi yang baik itu melibatkan berbagai cara/terobosan yang out of the box tidak hanya sekedar duduk, berkumpul, dan berbicara, namun juga harus tetap memperhatikan faktor-faktor potensial lain yang dapat meningkatkan tingkat kesuksesan dalam komunikasi. Pola komunikasi yang baru ini, kemudian akan berimbas kepada hasil pemecahan masalah, dengan pola baru ini sejatinya organisasi dapat menjadi lebih hidup, dan menyesuaikan tantangan zaman.

Tentunya hal itulah yang diperlukan pertama dalam penerapan budaya organisasi ini, selain itu kepemimpinan yang kreatif dan tidak berkutat pada satu cara, juga menjadi solusi terhadap 
macetnya kualitas kinerja di sel-sel organisasi, top manager harus mampu juga mengajak para pemimpin di luar lini yang disebut dengan "pasukan khusus" untuk dapat mengajak anggota lain supaya lebih agresif dan produktif lagi dalam bekerja.

\section{b. Faktor Penyebab}

Ada beberapa faktor yang memengaruhi di antaranya ukuran organisasi, lama berdirinya organisasi serta perputaran pegawai. Sementara itu ada tantangan yang harus dihadapi seperti bagaimana mempertahankan budaya organisasi serta bagaimana pelibatan pegawai dalam pembentukan dan penerapan budaya organisasi. Organisasi pada prinsipnya harus melakukan perubahanperubahan serta berani melakukan inovasi yang sustainable untuk menghadapi tantangan dunia kerja ke depan, dalam rangka surviving serta penguatan dan pembaharuan segala lini, mulai dari kualitas pegawai, kualitas pemecahan masalah, kualitas pemimpin masing-masing unit dan instansi, aksi dan cara yang dilakukan, kemudian sarana dan prasarana yang dapat menunjang perubahan ke arah yang lebih baik tersebut. Pada dasarnya Disdukcapil khususnya para pemimpin di dalam instansi tersebut tidak perlu takut untuk mengeksplorasi lebih jauh kebijakan, cara, metode, dan aksi yang hendak dilakukan, karena hakikatnya sekarang adalah zaman penuh inovasi, inovasi berbasis 4.0 yang mengandalkan pelayanan dan koordinasi yang cepat antar lembaga, serta internalisasi organisasi yang berbeda dari sebelumnya,lebih kreatif, humanif, tapi tetap dalam koridor sustainability, Leading advantage, efektif, dan efisien.

\section{c. Upaya yang Dilakukan}

$$
\text { Upaya yang dilakukan Disdukcapil }
$$$$
\text { Kabupaten Banjarnegara adalah dengan }
$$

cara meningkatkan kualitas komunikasi dan merubah pola kepemimpinan di dalam organisasi, serta dengan terbuka mengajak semua lapisan sel-sel organisasi untuk saling bahumembahu, menanamkan tanggung jawab, dan kepercayaan diri dalam rangka memajukan Disdukcapil Kabupaten Banjarnegara. Penerapan tekad untuk berinovasi dan selalu melakukan terobosan dalam diri masing-masing elemen organisasi juga dianggap perlu, dan menjadi upaya Disdukcapil Kabupaten Banjarnegara untuk meningkatkan kualitas budaya organisasi dan produktivitas daripada organisasinya tersebut sebagai dampak positif dari budaya inovasi yang terus sustainable di lingkungan staf dan pimpinan.

\section{SARAN}

Berdasarkan simpulan penelitian di atas, ada beberapa saran berikut.

\section{a. Untuk Dinas:}

Penerapan budaya organisasi dapat lebih ditingkatkan dengan memperhatikan faktor-faktor sebagaimana disebut di atas. Dengan mengetahui tantangan ke depannya Dinas diharapkan bisa mengantisipasi dengan tindakantindakan yang bisa mengurangi risiko.

\section{b. Untuk Penelitian Selanjutnya:}

Agar mengembangkan penelitian lebih dalam lagi tentang pengaruh budaya organisasi terhadap kinerja Dinas. dan juga agar melakukan penelitian tentang pengaruh budaya organisasi terhadap kinerja Dinas dengan menggunakan metode lain. 


\section{DAFTAR PUSTAKA}

Arikunto, S. (2010). Prosedur Penelitian. Jakarta: Rineka Cipta.

Buhler, P. (2004). Alpa Teach Yourself; Manajemen Skills dalam 24 Jam. Jakarta: Prenada Media.

Dinas Kependudukan dan Catatan Sipil Kab. Banjarnegara (2016). Sejarah Dinas Kependudukan dan Catatan Sipil

Dinas Kependudukan dan Catatan Sipil Kab. Banjarnegara (2018) Laporan Kinerja Instansi Pemerintah.

Fahmi, I. (2011). Manajemen Kinerja. Bandung: Alfabeta.

Gulo, W. (2010). Metode Penelitian (Penelitian Perspektif). Jakarta: PT. Grasindo.

Hardiyansyah. (2011). Kualitas Pelayanan Publik; Konsep, Dimensi, Indikator dan Impelementasinya. Yogyakarta: Gava Media.

Khumairoh, N., Juliati, L., \& Wediawati, T. (2018). Penerapan Budaya Organisasi Dalam Meningkatkan Kinerja Karyawan Pada PT Salim Surya Phone di Samarinda. Administrasi Bisnis, 1334-1346.

Kreitner, R., \& Kinicki, A. (2001). Organisation Behaviour. Singapore: McGraw-Hill.

Mangkunegara, N. P. (2005). Manajemen Sumber daya Manusia Perusahaan. Bandung: Remaja Rosdakarya.

Moleong, L. J. (2009). Metodologi Penelitian Kualitatif. Bandung: Remaja Rosdakarya.

Nimran, U. (1999). Perilaku Organisasi. Surabaya: Citra Media.

Nazir, M. (2011). Metode Penelitian. Bogor: Ghalia Indonesia.

Rivai, V. (2005). Manajemen Sumber Daya Manusia untuk Perusahaan, Dari Teori ke Praktik. Jakarta: Rajagrafindo Persada.

Robbins, S. (2008). Perilaku Organisasi. Edisi Kesepuluh. Jakarta: PT. Indeks.
Schein, E. H. (1997). Organizational Culture and Leadership. Second Edition. San Franscisco: Jossey-Bass Publishers.

Sobirin, A. (2011). Budaya Organisasi: Pengertian, Makna, dan Aplikasinya dalam Kehidupan Organisasi: Edisi Kedua. Yogyakarta: UPP STIM YKPN.

Soelistyarini. (2014). Cross Cultural Communication: Building Communication Competence Accross Culture. Surabaya.

Soemartono, Triyuni, \& Hendrastuti, S. (2011). Administrasi Kependudukan Berbasis

Registrasi. Bandung: Radja
Grafindo Persada

Sugiyono. (2011). Memahami Penelitian Kualitatif. Bandung: Alfabeta

Suwarto, \& Koeshartono, D. (2009). Budaya Organisasi. Yogyakarta: Universitas Atma Jaya.

Uno, B. H., \& Lamatenggo, N. (2012). Teori Kinerja dan Pengukurannya. Jakarta: Bumi Aksara.

Wasistiono, S. d. (2002). Menata Ulang Kelembagaan Pemerintah Kecamatan. Bandung: PKP STPDN.

Widaningsih, L., \& Busono, T. (2012). Aspek Budaya Dalam Penggunaan Ruang Terbuka Hijau. Jurnal Pendidikan Teknik Arsitektur.

\section{Dokumen Lainnya:}

Mitra Wacana (2018) Ada Persoalan Adminduk di Banjarnegara. https://mitra wacana. or.id/berita/ada-persoalan-admindukdijalatunda-banjarnegara/ Instansi Pemerintah (LAKIP) Dinas

Kependudukan dan Pencatatan Sipil Kabupaten Banjarnegara tahun 2017

Undang-Undang Nomor 24 Tahun 2013 tentang Perubahan Atas UndangUndang 23 Tahun 2006 tentang Administrasi Kependudukan 
Virioner " Vol. $12 \backslash$ No. 2\April 2020:365-385

Undang-Undang Nomor 23 Tahun 2014 tentang

Pemerintahan Daerah 


\section{Visioner}

Vol. $12 \backslash$ No. $1 \backslash$ Januari 2020 